\title{
MOTIVASI DALAM PELAYANAN MEMPENGARUHI \\ PENGAJARAN DAN PERILAKU
}

\author{
Oleh: \\ Calvin Sholla Rupa'
}

\section{BAB I \\ PENDAHULUAN}

\section{Latar Belakang Masalah}

Orang percaya dewasa ini harus menyadari bahwa banyak di antara pemimpinpemimpin gerejawi atau dengan kata lain hamba-hamba Tuhan yang tidak dengan sungguhsungguh melaksanakan tugas pelayanan seperti yang diinginkan oleh Allah. Mereka melayani karena ingin mendapatkan harta kekayaan. Arthur H. Graves mengatakan,

Yesus mengatakan bahwa gembala yang baik memberikan nyawanya bagi domba-domba. Tetapi gembala palsu menemukan cara-cara agar domba-domba itu memberikan semua miliknya kepada gembala. Betapa banyaknya uang dan pelayanan yang giat diberikan oleh para penganut ajaran sesat. Dalam ayat 14 petrus berbicara tentang orang-orang yang tertipu oleh guru-guru palsu sebagai orang-orang yang lemah yang terpikat.l

Hal yang diungkapkan oleh Graves ini banyak berkembang saat ini. Pemimpinpemimpin gereja atau yang disebut sebagai pendeta berusaha untuk memperkaya diri dengan cara menarik uang sebanyak-banyaknya dari anggota jemaat. Mereka memakai metodemetode atau cara-cara yang sangat menarik untuk mendapatkan uang dari jemaat Tuhan. Ada yang mengatakan bahwa supaya kamu diberkati maka kamu harus membawa persembahanmu kepada saya. Hal ini bertentangan dengan Alkitab. Menurut Alkitab, persembahan itu harus ditujukan kepada Tuhan (Maleakhi 3:6-12) dan bukan ditujukan kepada seseorang. Tetapi walaupun mereka dianggap penyesat tetapi perkataan mereka benar dan jemaat diberkati karena melakukan apa yang dikatakan oleh pendeta tersebut.

Efraim Abraham da Costa mengatakan,

Salah satu bentuk penyesatan yang banyak muncul dewasa ini adalah pengajaran yang bertujuan menyenagkan keinginan daging dan mengeksploitasi kepuasan dari dunia materi. Jemaat selalu diiming-imingi kekayaan, kehormatan dan mujisat demi kesenagan jasmani. Yesus pernah dicobai iblis untuk menyenangkan keinginan dagingnya. Ia didatangi iblis untuk menggunakan kuasa-Nya mengubah batu menjadi roti.2

Mereka mengatakan bahwa tidak ada orang Kristen yang menderita, semuanya hidup makmur, tidak terkecuali bagi hamba-hamba Tuhan atau pendeta. Hamba Tuhan yang menderita bukanlah hamba Tuhan yang sebenarnya karena pelayanan itu identik dengan berkat. Iman dan pelayanan seseorang selalu diukur dengan berkat.

Lanjut da Costa mengatakan,

Ketika motivasi pelayanan dan penginjilan kita dimotivasi oleh hal-hal materi, maka pasti mudah disesatkan. Itu adalah pintu iblis untuk menyesatkan umat. Banyak orang Kristen datang ke gereja hanya untuk cari mujisat mengubah batu menjadi roti; berubah dari miskin 
menjadi kaya; dari sakit menjadi sembuh. Orang -orang seperti ini pasti suatu saat akan gugur imannya. Mereka berpikir, "Masak ke gereja terus-terus tapi Tuhan tidak jamin?" Mereka lupa bahwa manusia hidup bukan hanya karena dari roti saja tetapi dari Firman. Jadi kekesatan dan penyesatan dapat muncul dalam bentuk sikap terhadap hal-hal materi.(3)

Pernyataan Abraham da Costa dapat disederhanakan bahwa motivasi yang salah dalam pelayanan akan menimbulkan ajaran sesat (guru-guru palsu).

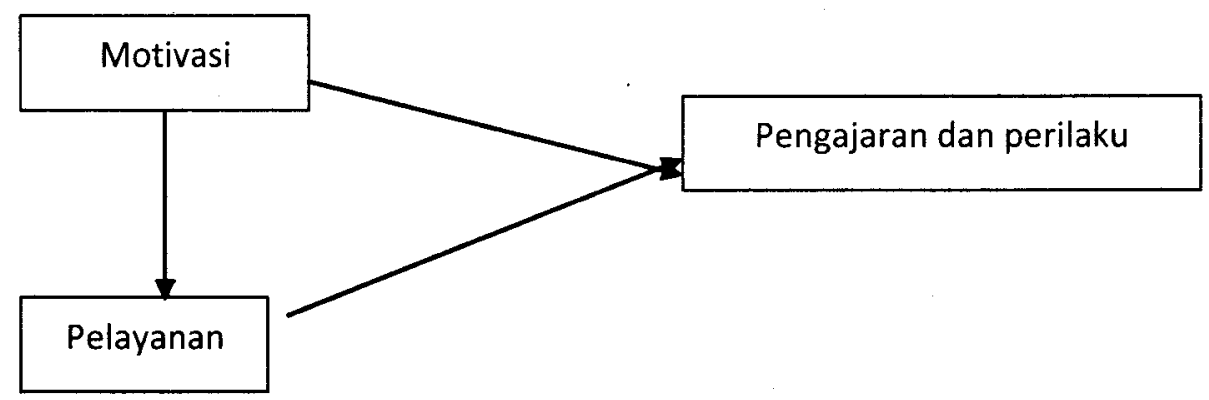

Dalam penelitian ini, peneliti ingin mencari hubungan antara motivasi dan pengajaran dan perilaku dalam pelayanan yang terdapat dalam IPetrus, 2Petrus dan 1Yohanes.

\section{Masalah Pokok}

Berkenaan dengan latar belakang di atas, maka penulis mengangkat beberapa masalah pokok yaitu:

Pertama, bagaimanakah hubungan antara motivasi dengan pelayanan?

Kedua, bagaimanakah hubungan antara pelayanan dengan pengajaran dan perilaku?

Ketiga, bagaimana hubungan antara motivasi dengan pengajaran dan perilaku?

\section{Tujuan Penelitian}

Adapun yang menjadi tujuan penelitian dari karya ilmiah ini adalah:

Pertama, untuk menemukan motivasi pelayanan guru-guru palsu.

Kedua, untuk mengetahui bentuk-bentuk pelayanan guru-guru palsu.

\section{Kegunaan Hasil Penelitian}

Adapun yang menjadi kegunaan hasil penelitian dari karya ilmiah ini adalah:

Pertama, untuk memberikan pemahaman kepada penulis dan pembaca mengenai pelayanan guru-guru palsu.

Kedua, sebagai bahan pegangan penulis untuk pelayanan. 


\section{BAB II \\ TINJAUAN PUSTAKA}

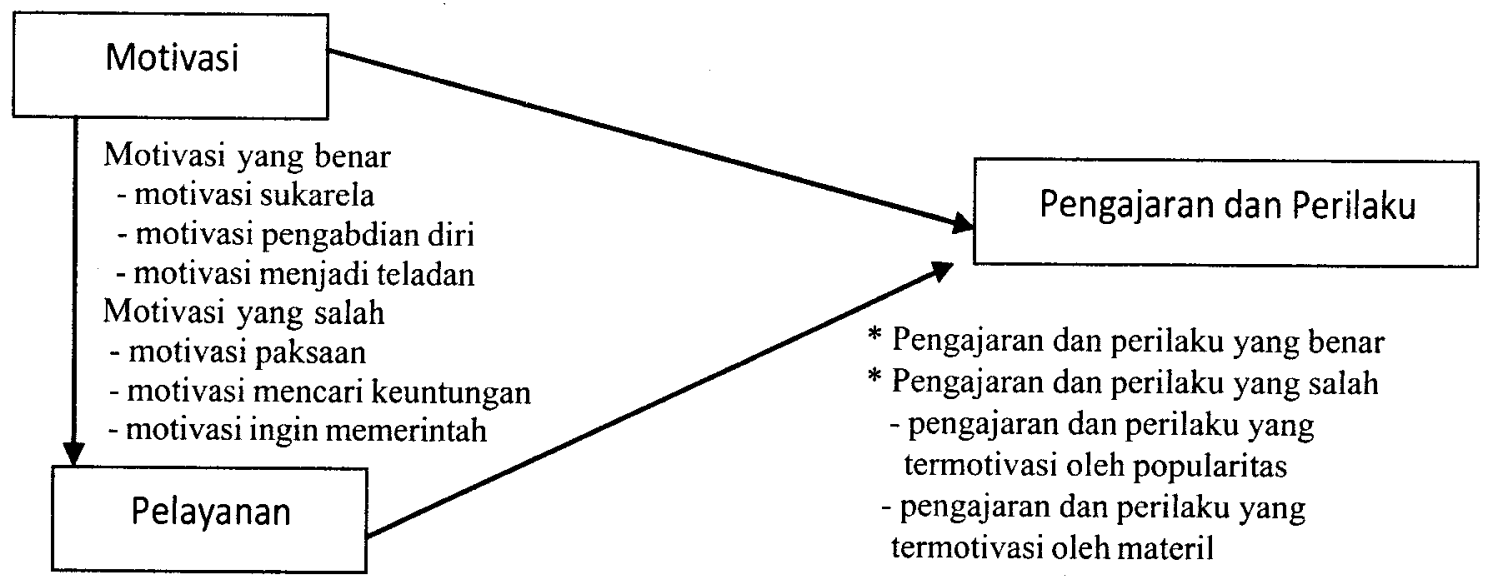

"Pelayanan (berkhotbah, mengajar, berkunjung) yang benar

" Pelayanan (berkhotbah, mengajar, berkunjung) yang salah

- Membawa kepada kesesatan

- Hanya menyenangkan hati manusia

- Menghujat kebenaran

\section{Motivasi}

Menurut Kamus, motivasi berarti "Keinginan, dorongan yang timbul pada diri seseorang, baik secara sadar maupun tidak sadar untuk melakukan suatu perbuatan dengan tujuan tertentu."1 Motivasi seseorang dalam melayani sangat menentukan kualitas pelayanan orang tersebut. Apabila motivasinya benar maka pelayanannya juga akan benar tetapi apabila motivasinya salah maka pelayanannya juga akan salah atau tidak sesuai dengan Firman Tuhan dan itulah yang disebut dengan pelayanan yang membawa kepada kesesatan.

\section{Motivasi yang Benar}

Hamba Tuhan yang benar melaksanakan tugas pelayanannya dengan benar karena motivasinya benar. Dalam surat lPetrus 5:2-3 menjelaskan tiga motivasi yang benar dalam pelayanan.

\section{Melayani dengan Sukarela.}

Pelayanan dengan sukarela ialah pelayanan yang dilakukan oleh seseorang yang memang karena keinginannya sendiri dan tanpa paksaan dari orang lain. Mereka melayani karena menyadari bahwa pelayanan itu mutlak dilakukan mengingat keselamatan yang Allah telah anugerahkan kepadanya.

\section{Melayani dengan Pengabdian Diri}

Pelahanan itu harus dilaksanakan dengan pengabdian diri atau dengan kata lain pelayanan yang tidak menuntut imbalan. Pelayanan dengan pengabdian diri biasanya hanya terjadi pada 
awal pelayanan seseorang. Setelah lama melayani maka pelayanan sukarela mulai luntur karena banyaknya kebutuhan hidup Hasan Sutanto mengatakan, "Dedikasi yang tinggi berawal dari motivasi yang murni dan kuat. Ini muda dijaga pada masa awal pelayanan pengkhotbah. Namun, dengan berlalunya waktu, keadaan akan berubah. Ada banyak faktor yang akan membuat dedikasi pengkhotbah menjadi berkurang, salah satunya adalah tuntutan kebutuhan hidup sehari-hari." 2 Pengabdian diri bukan berarti bahwa pelayan itu tidak boleh mendapatkan nafkah tetapi maksudnya ialah tidak menuntut imbalan. Hal ini jelas dalam 1Korintus 9:14, "Demikian pula Tuhan Telah menetapkan bahwa mereka yang memberitakan Injil, harus hidup dari pemberitaan Injil itu."

\section{Melayani dengan Tujuan Menjadi Teladan yang Baik}

Teladan yang baik mutlak dimiliki oleh pelayan Allah. Hamba Tuhan seakan-akan dijadikan sebagai tokoh yang dikagumi, dihormati, dll dalam masyarakat. Semua mata tertuju kepada hamba Tuhan atau pendeta sehingga mereka harus menjadi teladan yang baik. Kenyataan yang terjadi sekarang ialah bahwa begitu banyak hamba Tuhan yang tidak menjadi teladan yang baik begi jemaat dan justru menjadi batu sandungan bagi masyarakat. Tafsiran Alkitab mengatakan, "Dulu Petrus telah berhadapan dengan peristiwa dimana orang-orang Kristen ortodoks dihujat karena kelakuan mereka yang baik (lPetrus 3:16; 4:3-5), tetapi sekarang ia merasa sedih karena percabulan bidat-bidat Kristen yang pura-pura mencemarkan Iman Kristen yang benar."3

\section{Pelayanan}

Pengajaran seorang hamba Tuhan yang dilaksanakan dalam pelayanan apakah melalui khotbah, ceramah, perkunjungan, dll harus nampak atau diwujudkan dalam perilakunya. Ironisnya bahwa kadang seorang pengkhotbah mengatakan bahwa "itu adalah dosa" tetapi dia sendiri (pengkhotbah itu) yang melakukan apa yang dikatakannya itu dosa. Jika pelayanan salah maka pengajaran dan perilaku pelayan tersebut akan bertentangan dengan Firman Allah. Berikut adalah beberapa ciri pelayanan yang salah yang dibuat pada saat berkhotbah, mengajar, berceramah, melakukan perkunjungan dan bentuk-bentuk pelayanan yang lainnya.

\section{Pelayanan yang Salah}

\section{Membawa kepada Kesesatan}

2Petrus 2:1 mengatakan, "Sebagaimana nabi-nabi palsu dahulu tampil di tengah-tengah umat Allah, demikian pula diantara kamu akan ada guru-guru palsu. Mereka akan memasukkan pengajaran-pengajaran sesat yang membinasakan, bahkan mereka akan menyangkal penguasa yang telah menebus mereka dan dengan jalan demikian segera mendatangkan kebinasaan atas diri mereka."

Guru-guru palsu muncul di tengah-tengah umat Tuhan. Mereka sengaja memasukkan ajaran-ajaran yang akan menyesatkan umat Allah. Tafsiran Alkitab menjelaskan,

Kegiatan nabi-nabi palsu dihadapkan dalam U1 13:1-5; I Raj 13:18; 22:5-23; Yer 5:13,31; 6:13. Guru-guru palsu, mungkin kepalsuan tersebut ada hubungannya dengan pengajaran atau mereka 
mengaku diri selaku pengajar. Agaknya kedua-duanyalah yang dimaksudkan. Memasukkan, dalam kata kerja ini terkandung arti 'diam-diam', 'licik'. Artinya yang tepat ialah 'masuk secara menambahkan'. Pengajaran sesat berasal dari kata Yunani haireseis yang hanya berarti 'kepercayaan yang terpilih'. Dalam gereja haireseis mempunyai arti 'kepercayaan karena pilihan seseorang yang dilakukan dengan penuh kesadaran' (lain halnya dengan kepercayaan yang sebenarnya yang dinyatakan oleh Allah). 4

Melalui penjelasan di atas maka guru-guru palsu itu mengajarkan ajaran-ajaran yang menyesatkan dengan cara yang licik. Mereka dengan sengaja memasukkan ajaran-ajaran sesat ke dalam gereja dengan cara yang halus sehingga mudah diterima oleh orang-orang yang mendengar ajardnnya. Mereka memasukkan ajaran yang menyesatkan dengan cara yang licik dan halus. Walaupun cara mereka licik dan halus tetapi lama kelamaan akan diketahui oleh orang-orang yang percaya karena pada akhimya ajaran mereka akan menimbulkan masalah dalam gereja dan masyarakat. Jan S. Aritonang mengatakan, "Aliran ini secara resmi telah dilarang pemerintah untuk berkegiatan di Indonesia, dengan alasan bahwa aliran ini dinilai oleh pemerintah, bersama pemimpin organisasi agama atau gereja-gereja resmi - telah menyebarluaskan ajaran sesat yang menimbulkan keresahan dan gangguan dalam masyarakat dan bisa merusak kehidupan beragama di Indonesia. "5

Pelayanan Mereka Hanya untuk Menyenangkan Hati Manusia

Dalam pelayanannya, guru-guru palsu selalu berusaha menyenagkan hati manusia. Mereka memakai berbagai macam cara supaya jemaat menyenangi atau menyukai dia. Dalam berkhotbah, mereka menggunakan cerita-cerita isapan jempol untuk menyenangkan hati manusia. 2Petrus 2:3b berkata, "Dan karena serakahnya guru-guru palsu itu akan berusaha mencari untung dengan cerita-cerita isapan jempol mereka." Efraim Abraham da Costa mengatakan,

Salah satu bentuk penyesatan yang banyak muncul dewasa ini adalah pengajaran yang bertujuan menyenagkan keinginan daging dan mengeksploitasi kepuasan dari dunia materi. Jemaat selalu diiming-imingi kekayaan, kehormatan dan mujisat demi kesenagan jasmani. Yesus pernah dicobai iblis untuk menyenangkan keinginan dagingnya. Ia didatangi iblis untuk menggunakan kuasa-Nya mengubah batu menjadi roti. 6

Tidak jarang diantara orang Kristen masa kini yang mempunyai prinsip kehidupan untuk bersenang-senang. Pada saat mereka diperhadapkan kepada suatu pencobaan atau kesulitan, mereka akan lari dari persekutuan. Mereka menganggap bahwa kekristenan identik dengan kesenangan sehingga orang Kristen tidak akan mengalami penderitaan. Lanjut da Costa mengatakan,

Ketika motivasi pelayanan dan penginjilan kita dimotivasi oleh hal-hal materi, maka pasti mudah disesatkan. Itu adalah pintu iblis untuk menyesatkan umat. Banyak orang Kristen datang ke gereja hanya untuk cari mujisat mengubah batu menjadi roti; berubah dari miskin menjadi kaya; dari sakit menjadi sembuh. Orang-orang seperti ini pasti suatu saat akan gugur imannya. Mereka berpikir, "Masak ke gereja terus-terus tapi Tuhan tidak jamin?" Mereka lupa bahwa manusia hidup bukan hanya karena dari roti saja tetapi dari Firman. Jadi kekesatan dan penyesatan dapat muncul dalam bentuk sikap terhadap hal-hal materi.7

Dalam kehidupannya secara khusus dalam berkhotbah, guru-guru palsu memakai cerita cerita isapan jempol atau "cerita-cerita yang dikarang sendiri" (BIS) agar jemaat menyukai mereka dan ajarannya, seperti yang terdapat dalam 2Petrus 2:3b Dalam Tafsiran Alkitab, 


$$
\text { M J } \mathrm{K} \text { be aran }
$$

M

gguhn $9 \mathrm{~h}$

"T

0

$$
\text { o g }
$$

B

dik af

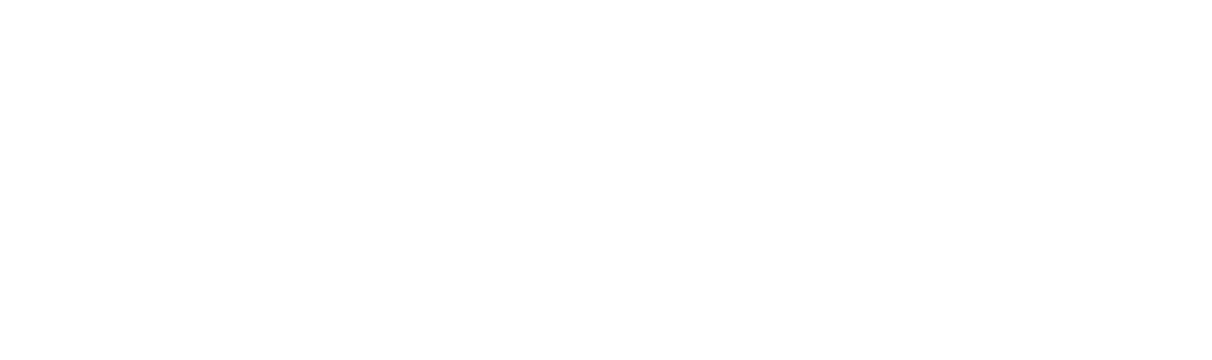

Al

arn

K 


\section{Pengajaran dan Perilaku}

\section{Pengajaran dan Perilaku yang Benar}

Pengajaran dan perilaku yang benar ialah pengajaran dan perilaku yang sesuai dengan ajaran Alkitab atau dengan kata lain bahwa pengajaran dan perilaku yang benar itu tidak menyimpang dari Firman Tuhan baik Perjanjian Lama maupun Perjanjian Baru.

Motivasi yang salah akan menimbulkan pengajaran (khotbah, ceramah, perkunjungan, dll) yang membawa kepada kesesasatan. Berikut ini akan dijelaskan tentang motivasi yang salah yang mempengaruhi pengajaran dan perilaku.

\section{Pengajaran dan Perilaku yang Salah}

\section{Pengajaran dan Perilaku yang Termotivasi oleh Popularitas}

Berdasarkan kamus, popularitas berasal dari kata "popular" yang sama dengan "terkenal" yang artinya "Dikenal dan disukai orang banyak atau mudah dimengerti oleh orang banyak. Terkenal mempunyai arti dikenal oleh orang banyak atau kenamaan."15 Guru-guru palsu muncul dan mereka melayani karena menginginkan ketenaran atau ingin terkenal dan mereka sangat menginginkan pelayanan mereka dipuji oleh manusia. Mereka melayani karena ingin dikenal bahwa ia adalah hamba Tuhan yang mampu berkhotbah dengan baik sehingga dalam menyampaikan Firman Tuhan selalu menonjolkan dirinya atau keluarganya melalui ilustrasi yang disampaikannya. Oliver Mc Mahan mengatakan,

Pengkhotbah tidak boleh melakukan hal apapun yang dapat mengalihkan perhatian jemaat dari tindakan Allah melalui Firman. Gerakan-gerekan dan ilustrasi hanya cocok selama dipusatkan pada Firman. Jika gerakan dan ilustrasi hanya bersifat subjektif atau menarik perhatian kepada diri si pengkhotbah sendiri dan bukan pada Firman, semua itu sebaiknya tidak digunakan. Allah harus dipandang sebagai hal yang lebih besar dibanding khotbah., Firman dan kuasa-Nya harus lebih besar dibanding si pengkhotbah.16

Pelayan Tuhan yang sebenarnya harus menyampaikan Firman itu bukan karena ingin dipuji tetapi karena mengganggapnya bahwa hal itu wajib ia lakukan dalam hidupnya karena merupakan tangung jawab yang harus dilaksanakan. Kewajiban dari hamba Tuhan ialah memberitakan Firman, bukan menyampaikan dongeng yang menyenangkan. Ellen $G$. White mengatakan,

Dalam kata-kata yang langsung dan tegas ini dijelaskan kewajiban pelayan Kristus. Ia harus memberitakan Firman itu, bukan pengajaran dan tradisi manusia, bukan cerita dongeng yang menyenangkan atau kisah-kisah yang menegangkan, untuk menggerakkan khayalan dan membangkitkan emosi. Pendeta harus berbicara dengan sungguh-sungguh dan ketekunan yang dalam, sebagai suara dari Allah yang menyingkapkan kitab yang kudus.17

Maksud dan tujuan Firman Tuhan disampaikan ialah supaya orang-orang yang mendengarnya digerakkan untuk bertobat atau mengubah hidupnya dan membuat seseorang lebih kokoh dalam hidup beriman kepada Tuhan. Linwood Urban mengatakan, "Baik dalam khotbah kaum terpelajar maupun dalam khotbah kalangan revivalis popular, kata-kata dari pengkhotbah memperantarai Firman Allah, dan ketika mendengarkan Firman itu para pendengar digerakkan untuk bertobat dan mengubah hidupnya."18 Tujuan tersebut tidak tercapai karena yang menyampaikan Firman Allah tidak mendasarkan khotbahnya pada tujuan itu sehingga Firman Tuhan yang disampaikan tidak menyentuh kehidupan pribadi setiap orang yang mendengarnya. 
Guru-guru palsu tidak hanya mencari popularitas melalui khotbah atau pada saat mereka menyampaikan Firman Tuhan tetapi juga melalui cara-cara lain. Banyak di antara mereka yang ingin memperkenalkan diri dan ingin disanjung atau ingin dikenal melalui karunia atau kemampuan khusus yang jarang dimiliki oleh orang lain seperti kemampuan menubuatkan sesuatu dan kemampuan melihat hal-hal yang tidak mampu dilihat oleh orang lain. Mereka mengatakan bahwa hal itu diperoleh langsung dari Allah seperti yang dijelaskan oleh tafsiran Alkitab, "Bermimpi-mimpian menyarankan bahwa guru-guru palsu itu mungkin mengatakan, bahwa mereka memperoleh ajaran-ajarah itu dari wahyu."19

Guru-guru palsu berusaha untuk mempengaruhi orang-orang yang telah mengerti tentang kebenaran dengan berbagai macam cara atau metode yang muda untuk diterima. "Bileam adalah lambang pengajaran palsu yang cukup dikenal, yang mencari keuntungan dan kepopuleran pribadi dengan mempengaruhi orang banyak, bahwa tuntutan Allah dapat ditawar."20

\section{Pengajaran dan Perilaku yang Termotivasi oleh Materil}

Kebutuhan hidup sehari-hari sangatlah mempengaruhi tindakan seseorang. Untuk memenuhi kebutuhan tersebut setiap orang memakai cara yang berbeda-beda. Ada orang yang memenuhi kebutuhan tersebut setiap orang memakai cara yang berbeda-beda. Ada orang yang memenuhi kebutuhan hidupnya dengan cara yang wajar seperti bertani, bekerja sebagai pegawai, tukang, dan lain-lain. Tetapi juga tidak jarang yang memenuhi kebutuhan hidupnya dengan cara yang tidak wajar seperti mencuri, melacur, berjudi, dan lain-lain.

Ada banyak orang yang ingin melayani seperti hamba Tuhan hanya karena ingin memenuhi kebutuhan hidupnya. Mereka beranggapan bahwa dengan menjadi pengkhotbah atau hamba Tuhan maka kebutuhan akan terpenuhi. Hamba Tuhan tidak bisa dilepaskan dari kebutuhan hidupnya. Stephen Tong mengatakan,

Saya bertemu dengan seorang pendeta di Singapura, yang sedang giat memberitakan Injil di Malaysia. Dia mengatakan bahwa di Malaysia banyak orang yang begitu responsive terhadap Firman Tuhan dan mereka mau percaya. Tetapi orang ini harus menjadi pendeta di Singapura, walaupun tidak sukses, karena kalau tidak jadi pendeta, tidak ada nafkah yang bisa didapatkannya.21

Banyak hamba Tuhan yang menjadikan pelayanan sebagai ladang bisnis, sehingga pelayanan yang dilakukannya semata-mata bertujuan untuk memperoleh uang atau materi sebanyak-banyaknya. Mereka tidak melayani seperti yang dilakukan oleh Tuhan Yesus yaitu rela memberikannya nyawa-Nya sendiri bagi domba-domba-Nya. Arthur H. Graves mengatakan,

Yesus mengatakan bahwa gembala yang baik memberikan nyawanya bagi domba-domba. Tetapi gembala palsu menemukan cara-cara agar domba-domba itu memberikan semua miliknya kepada gembala. Betapa banyaknya uang dan pelayanan yang giat diberikan oleh para penganut ajaran sesat. Dalam ayat 14 petrus berbicara tentang orang-orang yang tertipu oleh guru-guru palsu sebagai orang-orang yang lemah yang terpikat.22

Guru-guru palsu memakai berbagai macam metode atau cara dalam melayani dengan tujuan untuk memperoleh materi atau uang dari jemaat yang dipimpinnya. Mereka tidak memikirkan apakah cara itu sesuai dengan Firman Tuhan atau tidak, yang penting tujuannya untuk mendapatkan materi tercapai. Paulus D. H. Daun mengatakan, "Di Amerika gerakan 
mormon mempunyai areal tanah yang sangat luas, pabrik-pabrik dan usaha-usaha di bidang pertanian. Segala masalah jual beli yang mempunyai sangkut paut dengan perdagangan diatur oleh gereja. Hasil keuntungan digunakan untuk membeli saham, membangun gedung-gedung yang mewah dan mengembangkan propaganda agama mereka".23 Firman Tuhan mencatat dalam 2Petrus 2:15 bahwa guru-guru palsu meninggalkan jalan yang benar dan menempu jalan yang sesat seperti yang dilakukan oleh Bileam, anak Beor yang suka menerima upah untuk perbuatan-perbuatan yang jahat.

Pelayan-pelayan yang adalah guru-guru palsu selalu kuatir dalam kehidupannya mengenai apa yang hendak mereka makan dan pakai. Mereka tidak mempercayai Firman Allah yang mengatakan, "Demikian pula Tuhan telah menetapkan, bahwa mereka yang memberitakan Injil, harus hidup dari pemberitaan Injil itu." (IKorintus 9:14). Jika orang percaya secara khusus hamba-hamba Tuhan yang menginginkan hidup yang lebih baik maka harus bersandar sepenuhnya kepada Allah. Peter Wongso mengatakan bahwa manusia yang mau hidup dengan baik harus bersandar kepada Allah, menerima hidup yang berkelimpahan dan berkekuatan dari pencipta hidup yaitu Yesus Kristus. Dan memiliki hidup yang kuat di dalam kekekalan, Yesus Kristus hidup adanya, manusia hanya percaya dan menerimaNya sebagai juruselamat baru dapat hidup kekal.24

Guru-guru palsu melayani hanya karena menginginkan harta yang banyak. Mereka seakan-akan melaksanakan tugas pelayanan tetapi dengan motivasi yang salah yaitu melayani untuk perut mereka. Rasul Paulus menasihati jemaat di Filipi dengan mengatakan, "Karena, seperti yang telah kerap kali kukatakan kepadamu, dan yang kunyatakan pula sekarang sambil menangis, banyak orang yang hidup sebagai seteru salib Kristus. Kesudahan mereka ialah kebinasaan, Tuhan mereka ialah perut mereka, kemuliaan mereka ialah aib mereka, pikiran mereka semata-mata tertuju kepada perkara duniawi." (Filipi 3:19-19).

\section{Hipotesis}

Pertama, ada hubungan antara motivasi dengan pelayanan

Kedua, ada hubungan antara pelayanan dengan pengajaran dan perilaku?

Ketiga, ada hubungan antara motivasi dengan pengajaran dan perilaku?

\section{BAB III \\ METODE PENELITIAN \\ Variabel dan Desain Penelitian}

Variabel yang diteliti dalam penelitian ini adalah: 1). motivasi, 2). Pelayanan, dan 3). Pengajaran dan perilaku. Dalam penelitian ini, peneliti akan menemukan hubungan antara motivasi dengan pelayanan, hubungan antara pelayanan dengan pengajaran dan perilaku serta hubungan antara motivasi dengan pengajaran dan perilaku.

\section{Instrumen}

Dalam melaksanakan penelitian, peneliti menggunakan buku-buku atau literatur yang berhubungan dengan masalah di atas.

\section{Populasi}

Dalam melaksanakan penelitian, peneliti menggunakan seluruh buku yang ada di perpustakaan STT KIBAID. 


\section{Sampel}

Mengingat adanya buku-buku di perpustakaan STT KIBAID yang tidak berhubungan dengan karya ilmiah ini sehingga dalam melaksanakan penelitian, peneliti berfokus pada bukubuku tafsiran atau buku-buku teologi.

\section{Tekhnik Pengumpulan Data}

Penelitian ini menggunakan teknik pengumpulan data yaitu literature atau penyelidikan terhadap buku-buku dan tulisan-tulisan yang berkaitan dengan karya ilmfah ini secara khusus menggunakan buku-buku tafsiran dan teologi.

\section{Tekhnik Analisis Data}

Dalam menganalisa data, penulis penulis memakai tekhnik interpretasi yang bersifat eksegesis atau penyelidikan yang bersifat menerangkan Alkitab dimana berusaha mencari makna dari setiap kata dengan melihat kedalam bahasa asli dan menggunakan metode hermeneutik Alkitab atau penafsiran dari berbagai sumber sehingga menghasilkan data yang dapat dipertanggung jawabkan.

\section{Kritik Teks (Mencari Susunan Kata yang Asli)}

Pada saat membaca Alkitab, sering ditemukan bahwa ada perbedaan antara suatu tulisan yang satu dengan tulisan yang lain yang membahas suatu topik yang sama. John $\mathrm{H}$. Hayes mengatakan, Ketika mempelajari sebuah teks Alkitab, pada satu bagian Alkitab seorang penafsir seringkali menemukan susunan kata-kata yang berlainan, atau bacaan-bacaan yang bervariasi. Hal ini dapat terjadi ketika orang membaca bagian yang sama di dalam terjemahanterjemahan yang berlainan. Hal ini juga dapat ditemukan pada satu terjemahan, khususnya pada terjemahan yang merupakan edisi dari salah satu panitia besar penerjemah Alkitab (RSV, NEB, JB, NJV, NIV dan NAB). Apabila orang mengerti sifat naskah-naskah kuno alkitabiah, maka ia dapat menghargai mengapa notasi-notasi seperti itu muncul, apa maksudnya dan bagaimana memakainya.l

Dalam penelitian ini, penulis akan memakai kritik teks atau menyelidiki ayat-demi ayat berdasarkan bahasa aslinya.

\section{Kritik Histori}

Kritik historis adalah melihat sejarah dari teks itu dan sejarah dalam teks itu. Hayes mengatakan, "Kritik historis terhadap dokumen-dokumen didasarkan pada anggapan bahwa sebuah teks itu bersifat historis minimal dalam dua pengertian: teks itu berkaitan dengan sejarah dan juga memiliki sejarahnya sendiri."2 Peneliti juga akan memakai kritik historis dalam mengumpulkan data.

\section{Kritik Tata Bahasa}

Kritik tata bahasa dimaksudkan untuk mengetahui maksud penulis dalam teks itu. Hayes mengatakan, Kritik tata bahasa menaruh perhatian bukan hanya pada perihal bagiaman katakata berfungsi sebagai pembawa atau pengemban arti, tetapi bagaimana kata-kata itu disusun dalam frasa frasa dan dan kalimat kalimat untuk membentuk unit-unit yang bermakna. Maksud pendekatan ini adalah untuk menolong menciptakan kembalai alam pemikiran asli dari penulis dan memasukkannya melalui bahasa teks.3 


\section{Menghubungkan Ketiga Pendekatan di Atas}

Tujuan dari penafsiran ialah untuk memahami sebuah teks dengan jelas dan lengkap. Untuk memahami teks dengan jelas dan lengkap maka ketiga pendekatan di atas harus digunakan secara bersama-sama dankemudian menghubungkannya dengan keadaan pada masa sekarang.

\section{BAB IV \\ HASIL DAN PEMBAHASAN \\ Hubungan Antara Motivasi dengan Pelayanan}

Motivasi berkaitan erat dengan pelayanan seorang hamba Tuhan (pendeta, guru, dll). Rasul Petrus mengatakan, "Gembalakanlah kawanan domba Allah yang ada padamu, jangan dengan paksa, tetapi dengan sukarela sesuai dengan kehendak Allah. Melalui firman Allah ini, seorang hamba Tuhan dituntut untuk melayani karena motivasi sukarela dan bukan karena paksaan. Dan jangan karena mau mencari keuntungan, tetapi dengan penganbdian diri. Janganlah kamu berbuat seolah-olah kamu mau memerintah atas mereka yang dipercayakan kepadamu, tetapi hendaklah kamu menjadi teladan bagi kawanan dombaitu." (1Petrus 5:2-3) Rasul Petrus sebagai penulis dari kitab ini adalah orang yang tidak mau mencari keuntungan dalam pelayanannya. Arthur H. Graves mengatakan, "Dalam soal ini, Petrus tidak menuntut kedudukan atau pangkat yang akan membebaskan dia dari masalah itu."l Petrus adalah seorang pelayan Tuhan yang mengerti benar tentang hakekat pelayanan itu. Ia memberikan nasehat kepada para penatua supaya menggembalakan jemaat dengan baik. Adina Chapman mengatakan,

Petrus sebagai teman para penatua yang mengerti masalah mereka, menasehatkan mereka untuk menngembalakan kawanan domba Allah dengan baik. Syarat-syaratnya dibahas dengan terang dalam I Petrus 5:2-3. Dan semuanya itu akan dipertanggungjawabkan di hadapan Gembala Agung kelak (5:4). Yang bertindak dalam hawa nafsu akan menghasilkan buah hawa nafsu dalam dirinya sendiri. Ini bisa menjadi kerugian besar dalam jemaat seluruhnya. 2

Pendapat Chapman ini mengatakan bahwa yang melayani karena hawa nafsu atau karena motivasi yang salah maka hal itu akan nampak dalam pelayanannya. Jika motivasi salah maka bentuk pelayanan juga pasti salah atau menyimpang dari Alkitab. Motivasi yang salah dalam pelayanan akan membuat seseorang melakukan pelayanan (pelayanan mimbar, perkunjungan, pengajaran, dll) yang akan membawa kepada kesesatan.

\section{Motivasi yang Salah akan Menimbulkan Pelayanan Yang Membawa Kepada Kesesatan}

2Petrus 2:l mengatakan, "Sebagaimana nabi-nabi palsu dahulu tampil di tengah-tengah umat Allah, demikian pula diantara kamu akan ada guru-guru palsu. Mereka akan memasukkan pengajaran-pengajaran sesat yang membinasakan, bahkan mereka akan menyangkal penguasa yang telah menebus mereka dan dengan jalan demikian segera mendatangkan kebinasaan atas diri mereka."

Guru-guru palsu muncul di tengah-tengah umat Tuhan. Mereka sengaja memasukkan ajaran-ajaran yang akan menyesatkan umat Allah. Tafsiran Alkitab menjelaskan, Kegiatan nabi-nabi palsu dihadapkan dalam Ul 13:1-5; I Raj 13:18; 22:5-23; Yer 5:13,31; 6:13. 
Guru-guru palsu, mungkin kepalsuan tersebut ada hubungannya dengan pengajaran atau mereka mengaku diri selaku pengajar. Agaknya kedua-duanyalah yang dimaksudkan. Memasukkan, dalam kata kerja ini terkandung arti 'diam-diam', 'licik'. Artinya yang tepat ialah 'masuk secara menambahkan'. Pengajaran sesat berasal dari kata Yunani haireseis yang hanya berarti 'kepercayaan yang terpilih'. Dalam gereja haireseis mempunyai arti 'kepercayaan karena pilihan seseorang yang dilakukan dengan penuh kesadaran' (lain halnya dengan kepercayaan yang sebenarnya yang dinyatakan oleh Allah). 3

Ajaran-ajaran sesat dalam bahasa Yunani " (hairesis)" yang berarti "sekte; bidah; perpecahan; ajaran agama." 4 Peter Wongso mengatakan,

Bidat adalah suatu ajaran yang tidak sesuai dengan pengajaran doktrin Alkitab yang menyeluruh, yang bukan kebenaran ortodoks. Baik itu penambahan, maupun pengurangan tentang apa saja pada pengajaran kebenaran Alkitab yang ortodoks; atau terlalu memberikan penekanan pada suatu butir dan melalaikan butir yang lain; atau mengalih tafsirkan makna sebenarnya.5

\section{Motivasi yang Salah akan Menimbulkan Pelayanan yang Hanya}

\section{Untuk Menyenangkan Hati Manusia}

Dalam kehidupan pelayanannya secara khusus dalam berkhotbah, guru-guru palsu memakai cerita-cerita isapan jempol atau "cerita-cerita yang dikarang sendiri" (BIS) agar jemaat menyukai mereka dan ajarannya, seperti yang terdapat dalam 2Petrus 2:3b "Cerita isapan jempol dalam bahasa Yunani (plastois) yang berarti yang dibuat-buat." 6 Dalam Tafsiran Alkitab, "Isapan jempol, berarti diolah, dibuat untuk mengambil muka para pendengar. (bnd ITes 2:5)"7 Mereka mengarang sendiri cerita-cerita yang tidak sesuai dengan kebenaran dengan maksud untuk menyenangkan hati manusia tanpa peduli apakah hal tersebut sesuai dengan Firman Allah atau tidak. Baxter mengatakan,

Pelajarilah baik-baik peringatan Petrus dalam pasal dua itu. Kata "memikat" dalam ayat 14 dan 18 timbul dari dunia nelayan. Petrus teringat ketika ia mengail di Danau Galilea dahulu. Seolah-olah ia berkata: "hati-hatilah, penipu-penipu yang paling berbahaya ialah mereka yang datang membawa umpan yang enak dan kail yang tersembunyil" Pasal ini terus terang, tanpa kiasan. Segala sesuatu yang tidak memuliakan Kristus dan yang membinasakan jiwa, sekalipun dalam gereja sendiri, tak boleh dibiarkan! Pengajaran sesat janganlah disambut dengan ucapan manis. 8

\section{Motivasi yang Salah Menghasilkan Pelayanan yang Menghujat Kebenaran}

Dalam 2Petrus 2:2 dikatakan, "Banyak orang yang mengikuti cara hidup mereka yang dikuasai hawa nafsu, dan karena mereka jalan kebenaran akan dihujat." Menghujat dalam bahasa Yunani " (blasphemeo) yang berarti menghina; mengumpat; memfitnah."9 Karena motivasi yang salah maka pelayanan yang mereka lakukan menghujat kebenaran atau memutarbalikkan kebenaran itu. Graves mengatakan,

Satu hal yang selalu menyedihkan hati orang-orang yang mengasihi kebenaran adalah melihat betapa mudahnya orang banyak dibawa menjauhi kebenaran. Yang dimaksudnya ialah orangorang percaya yang nampaknya sudah bertobat sungguh-sungguh kepada Kristus, tetapi kemudian berpaling kepada suatu ide lain dan begitu terpikat oleh pikiran baru ini sehingga tidak seorang pun dapat mengembalikannya kepada imannya yang mula-mula.10 
Guru-guru palsu melaksanakan tugas pelayanan mereka untuk menyesatkan jemaat dengan ajaran-ajaran sesat yang seolah-olah benar tetapi sebenarnya bertentangan dengan firman Allah atau Alkitab. Mereka sangat pandai dalam memutarbalikkan kebenaran dengan ungkapan yang tidak jauh berbeda dengan yang sebenarnya sehingga dengan muda diterima oleh orang-orang yang mendengarnya. Arthur H. Graves mengatakan,

Sepanjang sejarah gereja, ajaran sesat dan doktrin palsu telah memutarbalikkan kebenaran mengenai Kristus, bukannya penyangkalan yang terus terang. Jika guru-guru sesat itu tidak menjadikan Yesus lebih rendah dari Allah, maka mereka berbuat yang sebaliknya, yaitu mengatakan bahwa Ialah satu-satunya Allah. Jika mereka tidak mengemukakan Dia sebagai manusia biasa, menyatakan bahwa ia adalah makhluk mistik, yang tidak ada persamaan dengan Kristus dari Galilea.ll

Alkitab mencatat, "Siapakah pendusta itu ? bukankah dia yang menyangkal bahwa Yesus adalah Kristus? Dia itu adalah anti Kristus, yaitu dia yang menyangkal baik Bapa maupun Anak." (IYohanes 2:22). Dalam 2Petrus 2:1 mengatakan, "Sebagaimana nabi-nabi palsu dahulu tampil di tengah-tengah umat Allah, demikian pula di antara kamu akan ada guruguru palsu. Mereka akan memasukkan pengajaran-pengajaran sesat yang membinasakan, bahkan mereka akan menyangkal penguasa yang telah menebus mereka dengan jalan demikian segera mendatangkan kebinasaan atas diri mereka." Penguasa dalam ayat ini diterapkan untuk Kristus, seperti yang dijelaskan oleh Tafsiran Alkitab Masa Kini 3, "Penguasa dalam bahasa Yunani: (despotes) hanya dalam ayat ini dan dalam Yudas 4 diterapkan untuk Kristus. "12

Guru-guru palsu mengajar atau menyampaikan Firman Tuhan kepada jemaat Tuhan dengan berbagai macam ajaran yang salah yang tidak sesuai dengan Firman Allah. Diantaranya, mereka menyangkal Kristus sebagai penguasa yang telah menebus manusia (2Petrus 2:1; Yudas 4). "Inti kesalahan mereka adalah kegagalan mereka untuk mengakui bahwa Yesus Kristus telah datang sebagai manusia."13

Guru-guru palsu mirip dengan ahli-ahli Taurat pada zaman Yesus. Mereka tidak mengakui bahwa Yesus adalah Mesias yang datang untuk menebus umat manusia yang berdosa. Walaupun mereka telah melihat tanda mujizat yang dilakukan oleh Yesus tetapi mereka juga tidak mau percaya karena anggapan mereka bahwa ia seorang anak tukang kayu (Matius 13:55-58). Guru-guru palsu juga hampir sama dengan agama Yahudi yang sampai saat ini masih menantikan akan kedatangan Mesias (Lukas 23:35-38). Mereka tidak mempercayai bahwa Yesuslah yang telah diutus oleh Bapa di sorga. Dalam 2Petrus 2:1 terdapat ungkapan "menyangkal penguasa." Alkitab Penuntun Hidup Berkelimpahan menjelaskan, "menyangkal" dalam Bahasa Yunani memakai kata (arneomai) yang berarti tidak mengakui atau meninggalkan."14

Guru-guru palsu sama dengan bidat. Paulus D.H. Daun mengatakan, "Bid(a)ah atau bidat berasal dari kata Arab yang mempunyai suatu ajaran atau aliran yang menyimpang dari ajaran resmi."15 Bidat atau aliran yang menyimpang dari kebenaran ini, menyampaikan ajarannya dengan cara menambahkan sesuatu kepada ketentuan yang telah digariskan. Paulus D.H. Daun mengatakan, "Bid'at, Bid'ah adalah suatu yang ditambahkan kepada apa yang tidak terdapat di dalam ketentuan-ketentuan yang sudah digariskan. "16 Organisasi Kristen yang mengaku percaya kepada Alkitab tetapi pada kenyataannya, ajarannya banyak yang menyimpang dari Alkitab maka organisasi itu bisa disebut sebagai bidat. Banyak organisasi 
atau persekutuan Kristen yang menyimpang dari kebenaran Alkitab. Mereka menafsirkan salah bagian Alkitab sehingga jemaat Tuhan dibawa kepada ajaran yang salah. Ada juga yang menambah atau mengurangi isi Alkitab atau bertolak Belakang dengan kebenaran Firman Allah, seperti yang dijelaskan oleh Paulus D.H. Daun, "Setiap organisasi manapun yang mengaku percaya pada Alkitab, tetapi keyakinan atau pengakuan tidak sesuai dengan Alkitab; terserah apakah isi Alkitab dikurangi, ditambah atau saling bertolak Belakang disebut sebagai Bidat."17 Mereka menyampaikan ajaran yang salah itu dengan cara yang begitu halus dan licik sehingga seolah-olah ajaran tersebut sesuai dengan ajaran Alkitab. Paulus D.H. Daun mengatakan, "Ciri-ciri yang akan sering kita temukan pada diri bidat-bidat yaitu mengemukakan pernyataan yang kelihatan benar tetapi sebenarnya salah."18

\section{Hubungan Antara Motivasi dengan Pengajaran dan Perilaku}

Motivasi atau hal-hal yang mendorong seseorang untuk melayani mempunyai hubungan yang erat dengan pengajaran dan perilaku pelayan itu.

Motivasi yang Salah akan Menimbulkan Pengajaran Dan Perilaku yang Salah

Motivasi pelayanan yang salah ialah motivasi karena paksaan, mencari keuntungan dan ingin memerintah jemaat. Seorang yang melayani karena motivasi yang salah akan menimbulkan pengajaran dan perilaku yang salah.

\section{Menghujat Sesuatu yang Tidak Diketahui}

Pelayan yang melakukan pelayanan karena motivasi yang tidak benar maka ia akan menghujat sesuatu yang tidak diketahui. Dalam pelayanannya, guru-guru palsu terlalu berani dan angkuh seperti yang terdapat dalam 2Petrus 2:10, "terutama mereka yang menuruti hawa nafsunya karena ingin mencemarkan diri dan yang menghina pemerintahan Allah. Mereka begitu berani dan angkuh, sehingga tidak segan-segan menghujat kemuliaan." Karena mereka terlalu berani dan angkuh sehingga mereka menghujat apa yang mereka tidak ketahui, seperti yang terdapat dalam Yudas 10, "Akan tetapi mereka menghujat segala sesuatu yang tidak mereka ketahui dan justru apa yang mereka ketahui dengan nalurinya seperti binatang yang tidak berakal, itulah yang mengakibatkan kebinasaan mereka." Menurut Tafsiran Alkitab, "Segala sesuatu yang tidak mereka ketahui diduga oleh beberapa kalangan, sebagai penunjukan kepada makhluk-makhluk sorgawi (seperti dalam ayat 8); tetapi ia bisa berarti hal-hal rohani."19 Jika dibandingkan dengan 2Petrus 2:10, maka sesuatu yang tidak mereka ketahui yaitu halhal yang rohani menunjuk kepada kemuliaan. Menurut Tafsiran Alkitab,

Mungkin kemuliaan dalam hal ini berarti malaikat-malaikat. Bila demikian maksudnya maka pengajar-pengajar sesat agaknya menghina malaikat-malaikat yang dimaksudkan sama seperti orang Sodom yang menghina malaikat yang singgah di rumah Lot (Kej 19:1). Kumungkinan lain mereka menyalahgunakan cerita perilaku malaikat-malaikat yang telah jatuh, sebagaimana dikemukakan dalam Kej. 6:1-4, dengan tujuan untuk membenarkan percabulan yang mereka lakukan. Bahkan mereka mencemarkan nama malaikat-malaikat yang tidak jatuh, sebab mereka menyamaratakan kelakuan semua malaikat. 20

Guru-guru palsu menghujat sesuatu yang mereka tidak ketahui. Mereka terlalu berani sehingga mereka berkata-kata tentang hal-hal yang rahasia, yang hanya Allah yang mengetahui hal itu. 
Pada zaman pelayanan gereja saat ini, sudah banyak orang yang menyebut dirinya sebagai hamba Tuhan yang terlalu berani sehingga mengungkapkan tentang saat atau waktu kedatangan Yesus Kristus yang kedua kali. "Salah satunya adalah pendeta Sibuayan yang berani mengatakan saat atau waktu kedatangan Yesus Kristus yang kedua kali."2l Guru-guru palsu sudah datang dan akan datang untuk menyesatkan banyak orang dengan perkataanperkataan mereka yang terlalu berani sehingga mereka menghujat sesuatu yang tidak mereka ketahui. "Guru-guru palsu sudah datang, nabi-nabi palsu akan datang. Sifatnya yaitu menyangkal Tuhan Yesus selaku penebus, penyesat dan munafik. Cara bekerjanya yaitu mencela yang benar, tamak, mencari untuk bagi diri sendiri." 22

\section{Memikat Hati Seseorang dengan Cara tidak Benar}

Guru-guru palsu berusaha untuk memikat hati orang-orang yang dilayaninya supaya orang-orang tersebut mengikuti ajarannya. Dalam 2Petrus 2:18 terdapat kata "memikat" yang menurut tafsiran Alkitab, "Memikat mengutarakan ciri dosa dari orang-orang yang sifatnya selalu membujuk serta meyakinkan orang lain untuk melibatkan diri dalam kelakuannya." 23 Mereka tidak meununtun orang-orang untuk datang kepada Kristus tetapi mereka berusaha supaya orang-orang yang dilayaninya jauh dari Kristus. Pelayan Allah yang sebenarnya membawa orang-orang untuk datang kepada Kristus tetapiguru-guru palsu berusaha memikat hati seseorang dengan cara yang tidak benar. Cara yang dipakai oleh guru-guru palsu untuk memikat hati seseorangialah,

\section{Seks}

Seks adalah suatu hal yang layak dibicarakan dan bukanlah hal yang tabu. Masalah seks adalah sesuatu yang hangat dibicarakan pada saat ini. Seks adalah salah satu bagian penting dalam kehidupan umat manusia. J.L.Ch. Abineno mengatakan,

Kita hidup pada suatu waktu, dimana seks dan soal-soal yang berhubungan dengan itu memainkan peranan penting. Hampir tiap-tiap hari koran-koran-banyak atau sedikit memuat berita-berita tantang kawin paksa, perkosaan, perzinahan, perceraian, pelacuran, dan lainlain. Demikian pula-majalah-majalah. Sebagian besar dari majalah-majalah itu, khususnya majalah-majalah wanita dan majalah-majalah hiburan, memilih seks-seperti: hubungan seksual sebelum menikah, hidup bersama tanpa ikatan perkawinan, pengguguran kandungan, penyakit kelamin, homoseksualitas, dan sebagainya- sebagai pokok pembahasan. Ya, yang banyak beredar pada waktu ini: hampir semuanya itu memakai tema yang diwarnai oleh seks.24

Guru-guru palsu memikat hati seseorang dengan mempergunakan seks karena hal itu merupakan salah satu bagian penting dalam kehidupan seseorang. Mereka memikat hati orang-orang yang lemah untuk terlibat dalam perzinahan karena mata mereka penuh dengan nafsu zinah (2Petrus 2:14). 2Petrus 2:18 mengatakan, "Sebab mereka mengucapkan katakata congkak dan hampa dan mempergunakan hawa nafsu cabul untuk memikat orang-orang yang baru saja melepaskan diri dari mereka yang hidup dalam kesesatan." Mereka menggoda semua orang mulai dari orang yang baru percaya sampai kepada orang yang sudah lama percaya yang dihormati dalam gereja.

Semua orang Kristen digoda untuk berdosa, mulai dari mereka yang baru percaya, sampai pada orang kudus yang dihormati. Seringkali mereka yang sudah paling berhasil justru mendapat cobaan paling berat dari iblis. Kita sedih melihat orang-orang Kristen mengalah pada dosa, dosa yang berat sekalipun, tetapi kita tidak perlu terperanjat. Kita hendaknya menyadari bahwa bila kita berjalan diantara banyak jerat, beberapa orang akan terjepit. 25 
Salah satu bentuk aliran sesat yang banyak menyesatkan pada zaman ini adalah "gereja setan". Mereka menggunakan seks sebagai bagian yang tak terpisahkan dari ibadah mereka untuk menyesatkan banyak orang. Hali Daniel Lie mengatakan, "Segala jenis kegiatan yang diselenggarakan dalam ibadah gereja setan dapat digolongkan atas tiga macam ritual: ritual seksual, untuk memuaskan erotisme; ritual kasih-sayang, untuk menolong seseorang; ritual destruktif, untuk menyatakan kemarahan, kejengkelan atau kebencian."26 Mereka menganggap hubungan seks sebagai perwujudan kasih bagi sesama.

\section{Menjanjikan Kemerdekaan/Kebebasan dari Tuntutan Alkitab}

Kemerdekaan atau kebebasan adalah suatu hal yang dinginkan oleh seseorang. Apabila seseorang mengalami penindasan maka ia menginginkan suatu kebebasan atau kemerdekaan. Marthinus Th. Mawere mengatakan, "Apalagi seiring dengan perkembangan tersebut muncul suatu telogi 'rakyat' yang menjadikan masalah kemerdekaan ataupun pembebasan sebagai wacananya. Tegasnya disebagian wilayah atau di dalam masyarakat kita yang mengalami ketertindasan baik dibidang sosial, ekonomi maupun politik, telah muncul cikal bakal teologi pembebasan." 27

Dalam 2Petrus 2:19 terdapat kata "kemerdekaan" yang dalam bahasa Yunani (eleutheria) yang berarti kebebasan; kemerdekaan. Kemerdekaan yang dimaksudkan dalam 2Petrus 2:19 bukanlah kemerdekaan dari penindasan dalam arti politik tetapi kemerdekaan dari tuntutan-tuntutan kepada Allah sebagai pegikut Kristus. Tafsiran Alkitab mengatakan, "Ternyata kemerdekaan yang dijanjikan oleh pengajar-pengajar palsu adalah kemerdekaan membebaskan diri dari kewajiban untuk mengabdi kepada Kristus dan bertumbuh di dalamNya, sebagaimana diuraikan dalam 1:3-1l. Dalam perlakuan demikian mereka melupakan bahwa kebebasan seperti itu hanyalah perhambaan kepada dosa kembali."28 Alkitab penuntun memberikan penjelasan tentang kemerdekaan yang dijanjikan oleh guru-guru palsu itu, Roh kedurhakaan yang menjanjikan kebebasan dari pembatasan ilahi akan merata, khususnya dalam masyarakat dan gereja pada hari-hari terakhir sebelum Kristus kembali. Patokan moral Allah yang mutlak akan dipandang kadaluwarsa dan hanya merupakan pengekangan hukum terhadap otonomi seseorang, rasa nyaman diri, dan kebahagiaan pribadi. Pada saat manusia menjadikan diri sebagai kekuasaan tertinggi, mereka menjadi hamba kebejatan moral.29

Banyak orang yang mengikuti ajaran guru-guru palsu (2Petrus 2:2) oleh karna mereka menjanjikan kebebasan dari tuntutan-tuntutan Alkitab. Guru-guru palsu memperbolehkan seseorang untuk menuruti hawa nafsunya (2Petrus 2:18). Jika orang tidak taat lagi kepada Firman Allah dan selalu hidup berkanjang di dalam dosa maka mereka akan gampang mengikuti ajaran yang sesat itu.

Selain kemerdekaan dari tuntutan hukum Allah, guru-guru palsu juga menjanjikan kemerdekaan yaitu kesenangan dalam kehidupan ini. Mereka menjanjikan kekayaan, kehormatan, mujizat, bebas dari penyakit dan pergumulan hidup. Abraham da Costa mengatakan, Salah satu bentuk penyesatan yang banyak muncul dewasa ini adalah pengajaran yang bertujuan menyenangkan keinginan daging dan mengeksploitasi kepuasan dari dunia materi. Jemaat selalu diiming-imingi kekayaan, kehormatan dan mujizat demi kesenangan jasmani. Ketika motivasi pelayanan dan pengiringan kita dimotivasi oleh hal-hal materi, maka pasti mudah disesatkan. 30

Seseorang atau sekelompok orang yang tertindas akan berusaha untuk membebaskan diri dari penindasan tersebut. Demikian halnya bagi bangsa Israel. Pada saat mereka mengalami 
penindasan dari bangsa-bangsa lain maka keinginan mereka ialah mendapatkan kemerdekaan. Marthinus Th. Mawere mengatakan, "Dijajah, ditindas, dan dijarah berulang kali oleh bangsabangsa musuh membuat Israel berusaha mencari solusinya. Solusi yang kemudian diperolehnya adalah perlunya suatu organisasi dan kepemimpinan nasional Israel yang kuat untuk dapat melindungi seluruh negeri Israel yang baru itu dari ancaman musuh."31

Orang-orang Kristen yang merasa tertindas atau terbebani oleh kewajiban-kewajiban untuk taat kepada Allah sebagai orang Kristen, kemungkinan mencari cara untuk membebaskan diri dari keterikatan itu. Mereka ini muda untuk mengikuti ajaran penyesat-penyesat karena ajaran penyesat menjanjikan kemerdekaan dari tuntutan-tuntutan Alkitab.

\section{BAB V \\ KESIMPULANDANSARAN \\ Kesimpulan}

Setelah peneliti melakukan penelitian, maka ada beberapa kesimpulan dari hasil penelitian ini:

Pertama, motivasi yang salah akan menimbulkan pelayanan yang membawa kepada kesesatan.

Kedua, motivasi yang salah akan menimbulkan pelayanan yang hanya untuk menyenangkan hati manusia.

Ketiga, motivasi yang salah menghasilkan pelayanan yang menghujat kebenaran.

Keempat, motivasi yang salah akan menimbulkan pengajaran dan perilaku yang salah.

\section{Saran}

Pertama, hendaknya pelayanan yang dilakukan bukan karena motivasi ingin mendapat kekayaan dan ingin mendapatkan popularitas.

Kedua, hendaknya dalam pelayanan, seorang pelayan mengajarkan tentang kebenaran dan bukan mengajar kepada kesesatan.

Ketiga, hendaknya dalam pelayanan, seorang pelayan mempunyai perilaku yang benar.

\section{KEPUSTAKAAN}

Alkitab

Alkitab. Jakarta: Lembaga Alkitab Indonesia, 2003.

Stamps, Donald C., ed. Alkitab Penuntun Hidup Berkelimpahan. Cetakan Pertama. Jakarta: Penerbit Gandum Mas bekerjasama LAI, 1994.

Sutanto, Hasan. Perjanjian Baru Interlinear Yunani-Indonesia dan Konkordansi Perjanjian Baru. Jilid I. Jakarta: LAI, 2003.

\section{Buku-Buku} 2000

Abineno, J.L.Ch. Seksualitas dan Pendidikan Seksual. Jakarta: BPK Gunung Mulia,

Aritonang, Jan S. Berbagai Aliran di dalam dan di Sekitar Gereja. Jakarta: BPK Gunung Mulia, 2000.

Barclay, Willaim. Pemahaman Alkitab Setiap Hari. Jakarta: BPK Gunung Mulia, 1995.

Bone, Darmawan S. Memerintah Sebagai Raja. Kalimantan Timur: Sekolah Tinggi Teologi Tenggarong, 1998.

Boyd, Frank M. Roh Kudus Penolong Ilahi. Malang: Gandum Mas, 1996. 
Cho, Paul Yonggi. Roh Kudus, Adimitra Saya. Jakarta: Yayasan Penerbit Injil Ianuel, n.d..

Daun, Paulus D.H. Bidat-Bidat Kristen dari Masa Ke Masa. n.p., 1987. Hidup, 1999.

Duewel, Wesley L. Menjangkau Dunia melalui Doa. Bandung: Yayasan Kalam

Getz, Gene A. Hiduplah dalam Kekudusan. Jakarta: BPK Gunung Mulia, 1993.

Graves, Arthur H. Pertama dan Kedua Petrus. Malang: Gandum Mas, 1982.

Handbook to the Bible. Bandung: Kalam Hidup, 2002.

Holmes, Arthur F. Segala Kebenaran adalah Kebenaran Allah. Surabaya: Penerbit Momentum, 2000.

Lahaye, Tim. dan Beverly LaHaye. Kehidupan Seks dalam Pernikahan. Bandung: Yayasan Kalam Hidup, n.d.

Lie,Hali Daniel. Gereja Setan di Indonesia. Bandung: Agiamedia, 2001

London, JR H.B. dan Wisemm, Neil B. Pelayan Allah yang Berjiwa Besar. Jakarta: Yayasan Pekabaran Injil Imanuel, 1999.

Mawere, Marthinus Th. Teologi Kemerdekaan. Jakarta: BPK Gunung Mulia, 2004.

Pfeiffer, Charles F. dan Harrison, Everett F. Tafsiran Alkitab Wycliffe, vol. 3. Malang: Gandum Mas, 2001.

Pola Hidup Kristen. Malang: gandum Mas, 1989.

Roni, K.A.M. Jusuf. Doa dan Iman. Yogyakarta: Yayasan Andi, 1999.

Subandrijo, Bambang, ed. Agama dalam Praksis. Jakarta: Gunung Mulia, 2003. Mulia, 2004.

Sutanto, Hasan. Homiletik. Prinsip Dan Metode Berkhotbah. Jakarta: BPK Gunung tum, 2001

Tong, Stephen. Kerajaan Allah, Gereja dan Pelayanan. Surabaya: Penerbit Momen-

Misi Pelayanan Sedunia .Jakarta: BPK Gunung Mulia, 1999.

Urban, Linwood. Sejarah Ringkas Pemikiran Kristen. Jakarta: BPK Gunung Mulia, 2003.

White, Ellen G. Pelayan Injil. Bandung: Indonesia Publishing House, 2002.

Wiersbe, Warren W. Berkemenangan di dalam Kristus. Bandung: Yayasan Kalam Hidup, 2002.

Wongso, Peter. Hamba Tuhan dan Jemaat Kristus yang Melintasi Zaman. Malang: Seminari Alkitab Asia Tenggara, 1997.

Dasar Iman Kepercayaan Kristen. Malang: Seminari Alkitab Asia Tenggala, 1993.

Latihan bagi Umat Allah. Malang: Seminari Alkitab Asia Tenggara, 1992.

Worthington, jr, Everett L. Ketika Seorang Berkata: Tolonglah Saya. Bandung: Kalam Hidup, n.d.

\section{Ensiklopedi/Kamus}

Ensiklopedi Alkitab Masa Kini. Jilid. II.Jakarta: Yayasan Komunikasi Bina Kasih/OMF, 1994.

Salim, Peter dan Yenny Salim. Kamus Bahasa Indonesia Kontemporer.Jakarta: Modern English Press, 1995.

Sutanto, Hasan. Perjanjian Baru Interlinear Yunani-Indonesia dan Konkordansi Perjanjian Baru. Jilid. II. Jakarta: LAI, 2003.

\section{Majalah}

Da Costa, Abraham. "Iblis Terlalu Bodoh jika Masuk Gereja dengan Identitasnya". Kasih 14, 2005. 